\title{
Histochemical and Immunohistochemical Analysis of the Stomach of Rhinella icterica (Anura, Bufonidae)
}

\author{
Clarice Machado-Santos, ${ }^{1}$ Adriana Alves Pelli-Martins, ${ }^{2}$ \\ Marcelo Abidu-Figueiredo, ${ }^{3}$ and Lycia de Brito-Gitirana ${ }^{2}$ \\ ${ }^{1}$ Biomedical Institute, Fluminense Federal University, 24210-130 Niterói, RJ, Brazil \\ ${ }^{2}$ Laboratory of Integrative Histology, Research Program in Glycobiology, Federal University of Rio de Janeiro, \\ 21941-902 Rio de Janeiro, RJ, Brazil \\ ${ }^{3}$ Animal Biology Department, Federal Rural University of Rio de Janeiro, 23890-000 Seropédica, RJ, Brazil
}

Correspondence should be addressed to Lycia de Brito-Gitirana; lyciabg.histo@gmail.com

Received 25 August 2014; Accepted 11 October 2014; Published 10 November 2014

Academic Editor: Francesco Cappello

Copyright (C) 2014 Clarice Machado-Santos et al. This is an open access article distributed under the Creative Commons Attribution License, which permits unrestricted use, distribution, and reproduction in any medium, provided the original work is properly cited.

\begin{abstract}
The stomach of Rhinella icterica was analyzed at light microscopy, employing histochemical techniques, lectin histochemistry, and immunohistochemistry for identifying enteroendocrine cells (EC). Although the stomach was composed of fundic and pyloric regions, its wall is formed by mucosa, submucosa, muscularis, and serosa. The mucosa was lined by a simple columnar mucous epithelium, supported by loose connective tissue. Several tubular, simple glands were composed of mucous neck cells, containing oxynticopeptic cells and EC cells. The mucous neck cells were rich in neutral glycoconjugates. The oxynticopeptic cells were predominant in fundic glands, exhibiting weaker alcianophilic reaction at their apical cytoplasm. Serotonin (5-HT) immunoreactive (IR) cells occurred throughout the entire stomach, preferentially located among mucous cells at upper part of the fundic glands. The muscularis mucosae, formed of smooth muscle, separated the mucosal layer from the submucosa, both of which were constituted by loose connective tissue, but without glands. Lymphoid modules occurred in the mucosa at the boundary at the stomach and the gut. In addition, the muscularis was constituted by two sublayers, the circular internal and the longitudinal external, being recovered by the connective tissue of the serosa.
\end{abstract}

\section{Introduction}

The structural organization of a tissue and/or an organ represents a close association between life habits and physiology of the animal; thus, the tissue structure can reflect their lifestyle and provide information for understanding the population declination and fluctuations $[1,2]$.

Morphological studies on the anuran gastrointestinal tube have been performed by histochemical [3-5], ultrastructural [6], and immunohistochemical techniques [7, 8], showing histological peculiarities to the stomach. These differences are more evident considering mainly the exocrine gastric glands, whose morphology varies according to the gastric region.

In mammals, the stomach is made up of mucosa, submucosa, muscularis, and adventitia or serosa. The gastric surface is recovered by a thin biofilm of mucous that is secreted by superficial mucous and mucous neck cells [9]. This mucous layer forms a highly viscous barrier that protects the stomach surface, being formed by acid and neutral glycoconjugates. Histochemical studies indicate differences regarding the qualitative expression of neutral, sulfated, and carboxylated mucosubstances $[10,11]$. The mucosubstances, which phylogenetically first appeared in mucous neck cells of the gastric glands of anurans [12], have already been reported for Rana aurora aurora [13], Bufo viridis [14], Rana perezi [15], Bufo melanostictus [3], and Bufo marinus [16], indicating variability among anuran species. Furthermore, different types of carbohydrates were identified in secretory cells in the stomach of Bufo viridis $[17,18]$ and Rana esculenta [19].

Regarding the specialized cells, studies of the stomach of adult frogs, as Rana esculenta [4] and Rana aurora aurora [13], as well as tadpoles of Rana temporaria [5] 
TABLE 1: Lectins, their sources, and inhibitory sugars.

\begin{tabular}{|c|c|c|c|c|}
\hline Source of lectin & Lectin abbreviation & Inhibitory sugar & Cat. vector no. & Dilution \\
\hline Griffonia simplicifolia & GSL-1 & $\alpha$-Gal, $\alpha$-GalNAc & B-1105 & $1: 500$ \\
\hline Arachis hypogaea & PNA & $\beta$-Gal>GalNAc & B-1075 & $1: 1000$ \\
\hline Artocarpus integrifolia & Jacalin & $\beta-\mathrm{Gal}>\mathrm{GalNAc}$ & B-1155 & $1: 500$ \\
\hline Lens culinaris & LCA & $\alpha$-Man, $\alpha$-Glc & B-1045 & $1: 500$ \\
\hline Glycine $\max$ & SBA & $\alpha>\beta$-GalNAc & B-1015 & $1: 1000$ \\
\hline Solanum tuberosum & STL & $\alpha / \beta-$ GlcNAc & B-1165 & $1: 1000$ \\
\hline
\end{tabular}

$\mathrm{Gal}=$ galactose, GalNAc $=\mathrm{N}$-acetylgalactosamine, $\mathrm{Man}=$ mannose, $\mathrm{Glc}=$ glucose, and GlcNAc $=\mathrm{N}$-acetylglucosamine .

demonstrated that oxynticopeptic cells occur in gastric glands, being responsible for hydrochloric acid production. Furthermore, oxynticopeptic cell has already been identified among glandular cells of the esophageal mucous layer of Rana catesbeiana [20] and Rhinella icterica [7]. In mammals, the production of pepsinogen as well as hydrochloric acid is performed by two distinct cell types [9]. On the other hand, in anurans, like Bombina variegata [4], Bufo marinus [21], B. viridis [14], Rana perezi [15], and Triturus carnifex [22], oxynticopeptic cells produce and release both hydrochloric acid and pepsinogen. Ruiz and coworkers [16] related the fact that, in B. marinus, oxynticopeptic cell is able to secrete pepsinogen concomitantly with hydrochloric acid.

The ontogeny and distribution of endocrine cell were studied in several mammalian species like humans [23], mice [24], and horses [25]. Santos and coworkers [26] indicate that in bats (Desmodus rotundus, Diphylla ecaudata, and Diaemus youngii) the relative frequency and distribution of these cells vary according to species and their feeding habits. In anurans, endocrine cells occur in the stomach of $R$. perezi [15], R. catesbeiana [27], and R. temporaria [28]. Nevertheless, information about the occurrence of enteroendocrine (EC) cells in the bufonid stomach is still limited.

It is well known that the function of the digestive tube is regulated by peptides, whose property makes some of them able to act as hormones. Moreover, peptides also exhibit other functions; for example, there are antimicrobial peptides involved in the innate immune response, being also called host defense peptides. In anurans, peptides with broadspectrum antimicrobial activities have been described not only in integument cells $[29,30]$ but also in peptic cells of the stomach [31,32]. Cho and coworkers [33] suggest that buforin $\mathrm{I}$, after being secreted into the gastric lumen, remains adhered to mucous that lines the stomach, providing a protective antimicrobial coat. This peptide exhibits other biological effects such as inhibition of botulinum, neurotoxins, and tissue factor-initiated coagulation. In addition, the anuran stomach is a general model for physiological investigations, being used for comparative purpose of the gastrointestinal tube development in vertebrates $[15,16,21]$.

The aim of this study is to characterize the histological structure of the stomach of Rhinella icterica, a common toad in Brazil, employing histochemical techniques at light microscopy level in order to improve the knowledge of the anuran digestive system. Moreover, this work also intends to detect different sugar secreting cell types using lectin histochemistry and identify 5-HT-, CCK-, G-, and STT-cells using immunohistochemistry.

\section{Material and Methods}

2.1. Animals. Nine adult male toads Rhinella icterica (former Bufo ictericus Spix, 1824) were collected according to Brazilian laws (collecting permit number 020222.003111/96-14 issued by IBAMA) in the District of Resende in Rio de Janeiro State.

2.2. Tissue Preparation and Staining. For light microscopic studies, stomach fragments were fixed in $10 \%$ buffered formaldehyde and/or in Bouin's liquid and were processed according to the standard histological techniques for paraffin embedding.

2.3. Light Microscopy. Five-micrometer-thick serial slices were stained with hematoxylin-eosin (HE) and Gomori's trichrome method [34]. Staining with $1 \%$ Alcian blue (AB) $8 \mathrm{GX}$ at $\mathrm{pH} 1.0$ and at $\mathrm{pH} 2.5$ [35] was employed for the demonstration of sulfated and sulfated and carboxylated acidic glycoconjugates, respectively. The periodic acid Schiff (PAS) staining was employed to detect neutral glycoconjugates [35].

2.4. Lectin Histochemistry. Lectin histochemistry was employed for carbohydrate detection, and the used lectins are listed in Table 1.

The biotinylated lectins GSL 1, STL1, PNA, Jacalin, LCA, and SBA were used, being purchased from Vector (Burlingame CA, USA).

Once dewaxed and hydrated, tissue slices were immersed in $3 \% \mathrm{H}_{2} \mathrm{O}_{2}$ for 10 minutes to suppress endogenous peroxidase activity, rinsed in $0.05 \mathrm{M}$ phosphate-buffered saline (PBS) at $\mathrm{pH} 7.4$, and incubated in lectin solutions of appropriate dilutions (Table 1) for 1 hour at room temperature. After three times of being washed in phosphate buffered saline (PBS), peroxidase activity was detected by incubation in a solution containing $0.05 \% 3,3^{\prime}$-diaminobenzidine tetrahydrochloride (DAB) and $0.005 \% \mathrm{H}_{2} \mathrm{O}_{2}$ in $0.05 \mathrm{M}$ PBS (pH 7.4) for 1 minute at room temperature before dehydration and mounting. As for the controls for lectin reaction, the incubation medium with buffer but without lectin was used. 
TABLE 2: Primary antibodies used and their respective dilutions (phosphate-buffered saline + albumin), supplier, and antigen recovery buffer.

\begin{tabular}{lccc}
\hline Antibodies & Dilution & Supplier & Cat. no. \\
\hline $\begin{array}{l}\text { Anti-serotonin } \\
\text { (5-hidroxytryptamine, }\end{array}$ & $1: 8000$ & Sigma-Aldrich & S 5545 \\
$\begin{array}{l}\text { 5-HT) } \\
\begin{array}{l}\text { Rabbit anti-human gastrin } \\
\text { (G) releasing peptide }\end{array}\end{array}$ & $1: 400$ & Sigma-Aldrich & A429 \\
$\begin{array}{l}\text { Rabbit anti-human } \\
\text { somatostatin (STT) }\end{array}$ & $1: 300$ & Dako & A0566 \\
$\begin{array}{l}\text { Rabbit polyclonal } \\
\text { anti-cholecystokinin } \\
\text { (CCK) }\end{array}$ & $1: 8000$ & Sigma-Aldrich & C 2581 \\
\hline
\end{tabular}

2.5. Immunohistochemistry. For immunohistochemistry, paraffin sections were dewaxed, hydrated, and washed in phosphate buffered saline (PBS). They were incubated with methanol containing $0,3 \% \mathrm{H}_{2} \mathrm{O}_{2}$ for 15 minutes to block any endogenous peroxidase. Sections were incubated with a $1: 100$ dilution of bovine serum albumin (B4287; Sigma) in PBS in a humid chamber during 30 minutes at room temperature. They were then incubated overnight with different antibodies (Table 2) at $4^{\circ} \mathrm{C}$. Afterwards, they were after that incubated with biotinylated secondary antibody diluted to $1: 200$ (PK 7200, Vector Laboratories, Inc., UK) for 30 minutes, then they were diluted at $1: 200$, for 30 minutes (both from PK 6200 , Vector Lab. Inc.). Subsequently, the peroxidase label was revealed by reaction with $\mathrm{DAB}$ at room temperature before dehydration and mounted using Enthelan (Merck).

\section{Results}

The stomach of $R$. icterica showed two regions: the fundic (Figure 1) and the pyloric regions (Figure 2). The gastric wall of both regions was formed by four major layers: mucosa, submucosa, muscularis, and serosa (Figure 1).

The mucosa showed gastric folds, and it was made of the lining epithelium supported by the lamina propria of loose connective tissue (Figure 1). The mucosa of the fundic and pyloric regions was lined by a simple columnar mucous epithelium (Figures 3 and 6). Occupying the entire mucosa, gastric glands opened into the bottom of the funnel-shaped depressions, named gastric pits (Figure 6). At pyloric region, the gastric folds were more prominent, while the gastric pits were deeper when compared to the fundic region (Figure 2).

Apical domain of the lining epithelial cells was acidophilic and exhibited strong staining after PAS (Figure 4) and PAF methods, but only a very weak alcianophilic reaction was observed at their surface (Figure 5). These histochemical findings indicated that their intake was rich in neutral glycoconjugates. The mucosa was separated from submucosa through muscular mucosa (Figures 1 and 6), which was clearly subdivided into inner circular and external longitudinal layers. At pyloric region, the muscular mucosa was subdivided into longitudinal internal and circular external layers (Figures 1 and 6). Isolated nodular lymphoid tissue

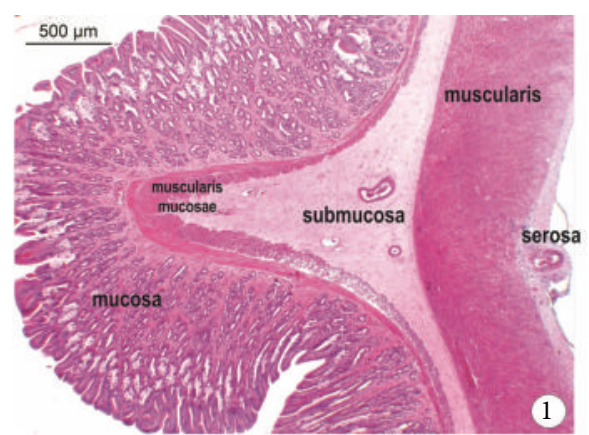

FIGURE 1: Light micrograph of the fundic region of the stomach of $R$. icterica. Note the mucosa, submucosa, muscular, and serosa layers. Gastric glands occupy the mucosa layer, being formed by mucous neck cells, predominantly at the upper portion, and oxynticopeptic cells, preferentially located at the lower portion. The muscular layer of smooth muscle is subdivided into longitudinal internal and circular external layers. HE staining.

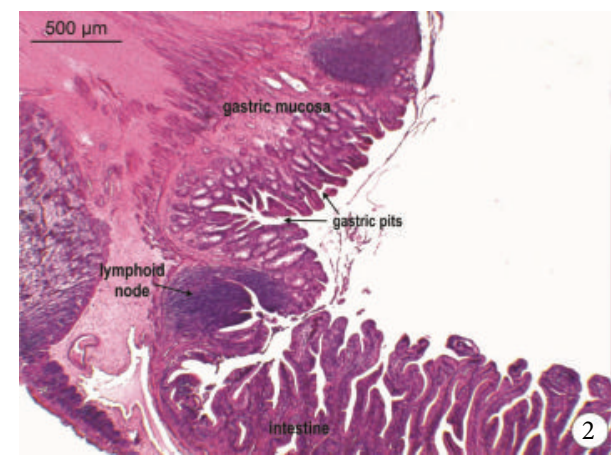

FIGURE 2: Light micrograph of the pyloroduodenal junction of the stomach of R. icterica. At pyloric region, prominent gastric folds are evident. Isolated lymphoid nodes occur in mucosa at transition from the stomach to the intestine. HE staining.

occasionally occurred in the mucosa connective tissue and was frequently visualized in the mucosa layer at the pyloroduodenal junction (Figure 2).

The gastric glands were structured as simple tubular gland, frequently branched at the lower portion of the gland body (Figure 3 ). They were constituted by mucous neck cells, preferentially located at the neck (Figures 1, 3, 4, and 6), besides oxynticopeptic cells, which predominate at the gland body (Figure 3). Beyond these cells, EC cells occur scattered through the gland body but predominated at the neck among mucous neck cells (Figure 7).

The mucous neck cells were lightly stained in bright purple after PAS staining (Figure 4); however, no AB reaction was visualized (Figure 5), indicating that their content is rich in neutral glycoconjugates.

Oxynticopeptic cells showed finely granular acidophilic cytoplasm (Figures 3 and 6) and are numerous mainly in the lower portion of the gastric gland. These cells predominate at the fundic region, decreasing until the pyloric region, where the gastric glands were basically formed by mucous cells 


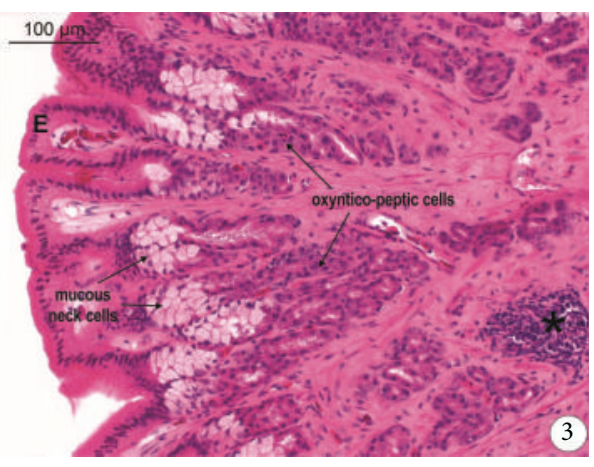

FIGURE 3: Light micrograph of the fundic region of the stomach of R. icterica. Mucosa is lined by simple columnar mucous epithelium (E), which forms simple tubular gastric glands composed of mucous neck cells at the upper portion of the gland and oxynticopeptic cells at lower portion. Isolated lymphoid nodules $(\star)$ occur in mucosa. HE staining.

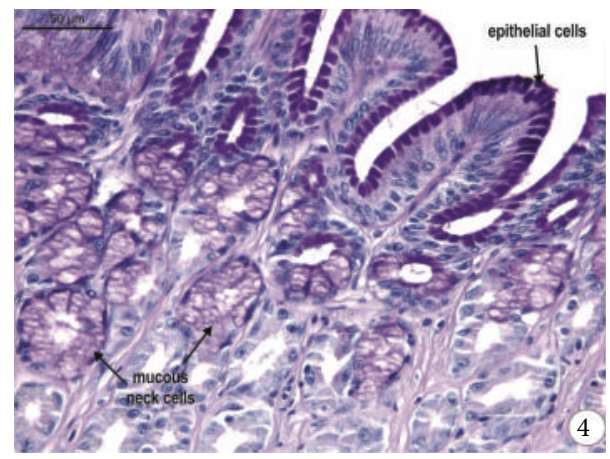

FIGURE 4: Light micrograph of the fundic region of the stomach of $R$. icterica. Glycoconjugates are identified at apical domain of the lining epithelial cells and at mucous neck cells. PAS method.

(Figure 2). In addition, they showed no PAS staining; nevertheless, weak alcianophilic reaction at the apical cytoplasmic domain was detected (Figure 5).

5HT-IR cells occurred throughout the lining epithelium of both fundic and pyloric regions of the stomach at the base of the pit near the neck of the gastric gland and at the upper portion of the fundic glands among the mucous neck cells (Figure 7). 5-HT-IR cells displayed triangular shape, exhibiting projections that reach the lumen, being classified as open type (Figure 7, inset). Moreover, the close type of 5HT-IR cell was also visualized. On the other hand, STT-, CCK-, and G-IR cells were not detected in any region of the stomach.

Separating both connective tissues (of mucosa from that of submucosa) there was well-defined muscularis mucosa, which was formed by two layers: the inner circular and the outer most longitudinal, both composed of smooth muscular tissue (Figures 1 and 6). The submucosa was also formed by loose connective tissue, rich in blood vessels; however, no glands were visualized in this layer.

In both fundic and pyloric regions, the muscular layer also consisted of smooth muscle, subdivided into the circular and longitudinal layers (Figures 1 and 6).

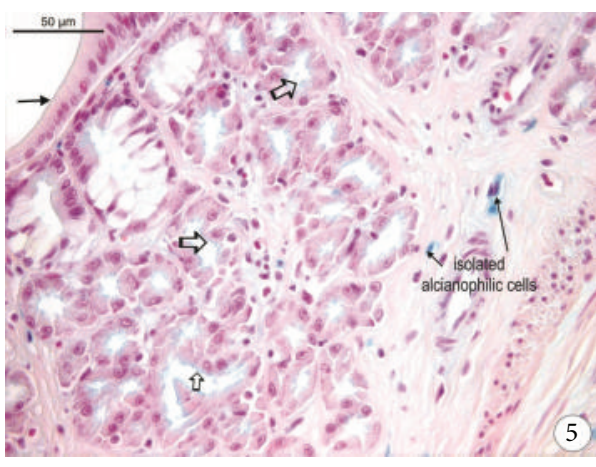

FIGURE 5: Light micrograph of the fundic region showing alcianophilic reaction at apical domain of the oxynticopeptic cells of the stomach of $R$. icterica. Note the isolated alcianophilic cells in the connective tissue of the mucosa layer. AB method.

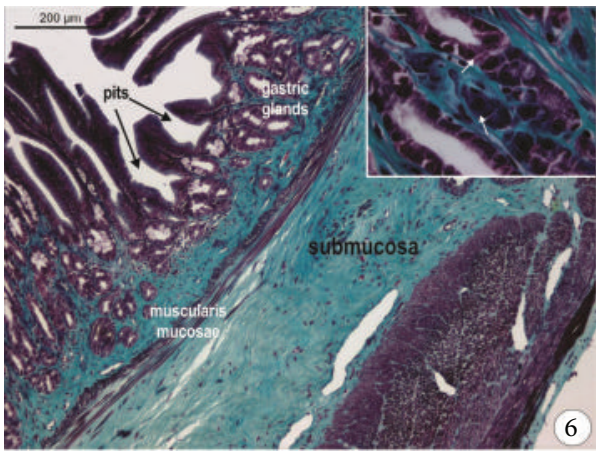

FIGURE 6: Light micrograph of the pyloric region of the stomach of $R$. icterica. The gastric pits are deeper when compared to the fundic region. Inset: detail of the gastric glands; the oxynticopeptic cells exhibit granular material scattered through their cytoplasm. Gomori's trichrome method.

The serous layer was identified through a very thin sheet of loose connective tissue with some blood vessels and nerves, being recovered by the mesothelium (Figure 1).

Considering the lectin histochemistry, glycoconjugates residues exhibited preferential localization in the stomach (Figures $8(\mathrm{a})-8(\mathrm{~d})$ ).

The epithelial cells showed reaction to employed lectins, except to STL, indicating that their intake contained more $\alpha>\beta$ GalNAc residues than $\alpha$-Gal, $\alpha$-GalNAc, and $\beta$ Gal $>$ GalNAc residues (see Table 3). However, $\alpha>\beta$-GalNAc residues predominated at epithelial cells of the gastric pits at the pyloric region (Figure 8(c)). The mucous neck cells from fundic and pyloric regions displayed positive reaction to GSL1, PNA, Jacalin, LCA, and SBA, except to STL, indicating $\alpha$-Gal, $\beta$-Gal, $\alpha$-Man, $\alpha$-Glc, and $\alpha$-GalNAc residues. The oxynticopeptic cells showed less $\alpha$-Gal, $\beta$-Gal, and $\alpha, \beta$-GalNAc, while $\alpha$-Man, $\alpha$-Glc residues were not detected. After lectin histochemistry, the extracellular matrix also revealed glycoconjugates as $\alpha$ Man, $\alpha$-Glc, and $\alpha$-GalNAc residues, probably due to its glycosaminoglycans.

The lectin reactions are summarized in Table 3. 
TABLE 3: Lectin histochemical labeling in the stomach of R. icterica.

\begin{tabular}{|c|c|c|c|c|c|}
\hline Lectins & Inhibitory sugar & Epithelial cells & Mucous neck cells & Oxynticopeptic cells & MEC \\
\hline GSL1 & $\alpha$-Gal, $\alpha$-GalNAc & +++ & ++ & + & + \\
\hline PNA & $\beta$-Gal $>$ GalNAc & ++ & ++ & $+1-$ & - \\
\hline Jacalin & $\beta$-Gal $>$ GalNAc & ++ & ++ & + & $+1-$ \\
\hline LCA & $\alpha$-Man, $\alpha$-Glc & + & + & - & ++ \\
\hline SBA & $\alpha>\beta$-GalNAc & +++ & ++ & + & - \\
\hline STL & $\alpha / \beta$-GlcNAc & - & - & + & - \\
\hline
\end{tabular}

$(+)$ weak positive reaction; $(++)$ moderate reaction; $(+++)$ strong reaction; $(-)$ negative reaction.

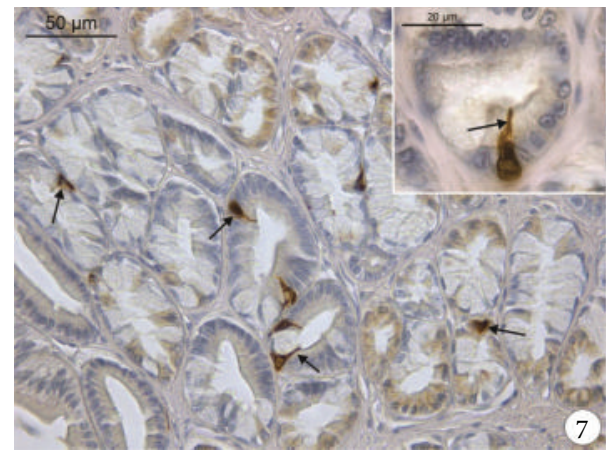

FIGURE 7: Immunohistochemistry for the 5-HT-IR cell identification. The 5-HT-IR cells $(\rightarrow$ ) occur among the lining epithelium and glandular cells of gastric glands. Inset: detail of the open type of 5HT cells, showing cytoplasmic processes $(\rightarrow)$ that arise glandular lumen.

\section{Discussion}

In $R$. icterica, the stomach presented four distinct layers, showing the same pattern for the digestive tube as described for its esophagus [7] and for other vertebrates [5, 36, 37]. Like in $R$. pipiens [38] (Norris, 1959) and $R$. aurora aurora [13], the stomach was characterized by two gastric regions: fundic and pyloric. Nevertheless, Gallego-Huidobro and Pastor [15] noticed that in $R$. perezi the fundic region is subdivided into upper and lower portions.

In adult $R$. icterica, the gastric mucosa is constituted by a simple epithelium of columnar mucous cells supported by well vascularized loose connective tissue. In addition, in fundic glands, mucous cells predominated at the neck, while oxynticopeptic cells were preferentially located at the body region. For other anurans, the lining epithelium is constituted by mucous ciliated cells, as in the larval stage of Xenopus laevis [39] and in R. temporaria [5].

After using histochemical methods, it could be seen that in R. icterica the mucous cells produce neutral glycoproteins, rich in galactose, galactosamine, and glucosamine residues.

As a family of heavily glycosylated proteins, mucins are the major organic components of mucous, representing the protective layer that recovers the epithelium in many organs of human and animals, including the gastrointestinal tube [40]. It is well known that gastrointestinal mucins are glycoconjugates that contain various amounts of different carbohydrate moieties [41], produced by epithelial and goblet cells [9].

Mucous cells have already been described in the stomach of mammals, as Rhesus monkey and baboon [11], as well as in other vertebrates as fishes [42] and lizards $[10,18]$.

According to Suganuma and coworkers [12], amphibians were the first vertebrates to develop true mucous neck cells, which are the precursors of chief cells via intermediate cells [31]. In anurans, mucins are produced by goblet cells found in the esophagus and the intestines, but also by epithelial cells and mucous neck cells in the stomach [43]. In $R$. icterica, mucous neck cells of fundic region produce neutral glycoprotein, rich in galactose residues, similar to those of $R$. esculenta [19], Ceratophrys ornata [44], Ceratophrys chalcides [10], and reptile Natrix natrix [45].

In R. aurora aurora, epithelial cells of the stomach exhibit both PAS and $\mathrm{AB}$ reaction. However, these findings are partly in contrast to our observations, since mucous cells of the fundic and pyloric glands of $R$. icterica displayed positivity only for PAS method. Yet, our results corroborated the reports by Loo and Wong [3], who described that the lining epithelial cells of the stomach of $B$. viridis and B. melanostictus produce only neutral mucins. Moreover, lectin histochemical studies revealed that in $R$. aurora aurora [13], B. viridis [14], and $R$. esculenta [19] mucous secreting superficial cells produce galactose, but not galactosamine, since in B. viridis [14] and $R$. aurora aurora [13] gastric secretion is rich in galactose and mannose.

In $R$. icterica, the epithelial superficial cells produced galactose $>$ galactosamine, being similar to those cells of Reptilia Chalcides chalcides [10]. Furthermore, galactose and $\alpha$-N-acetylgalactosamine were detected at apical domain of oxynticopeptic cells, that is, at the same localization as that of alcianophilic reaction. This result is probably peculiar to amphibians as $R$. icterica, Triturus carnifex [22], and other vertebrates, like seps (Chalcides chalcides) [10] and snake (Natrix natrix) [45], since epithelial cells exhibited very weak alcianophilic reaction. On the other hand, $\alpha-\mathrm{N}$ acetylgalactosamine residue has been reported to bind specifically not only in the intracellular canaliculi and vesicular membranes of mammalian parietal cells [46-48] but also in oxynticopeptic cells of some nonmammalians, such as the green toad B. viridis [14] and the ruin lizard Podarcis sicula campestris [49]. Moreover, in R. aurora aurora, oxynticopeptic cells showed no reaction to any of the used lectin kinds [13]. Liquori and coworker [22] suggest that differences 

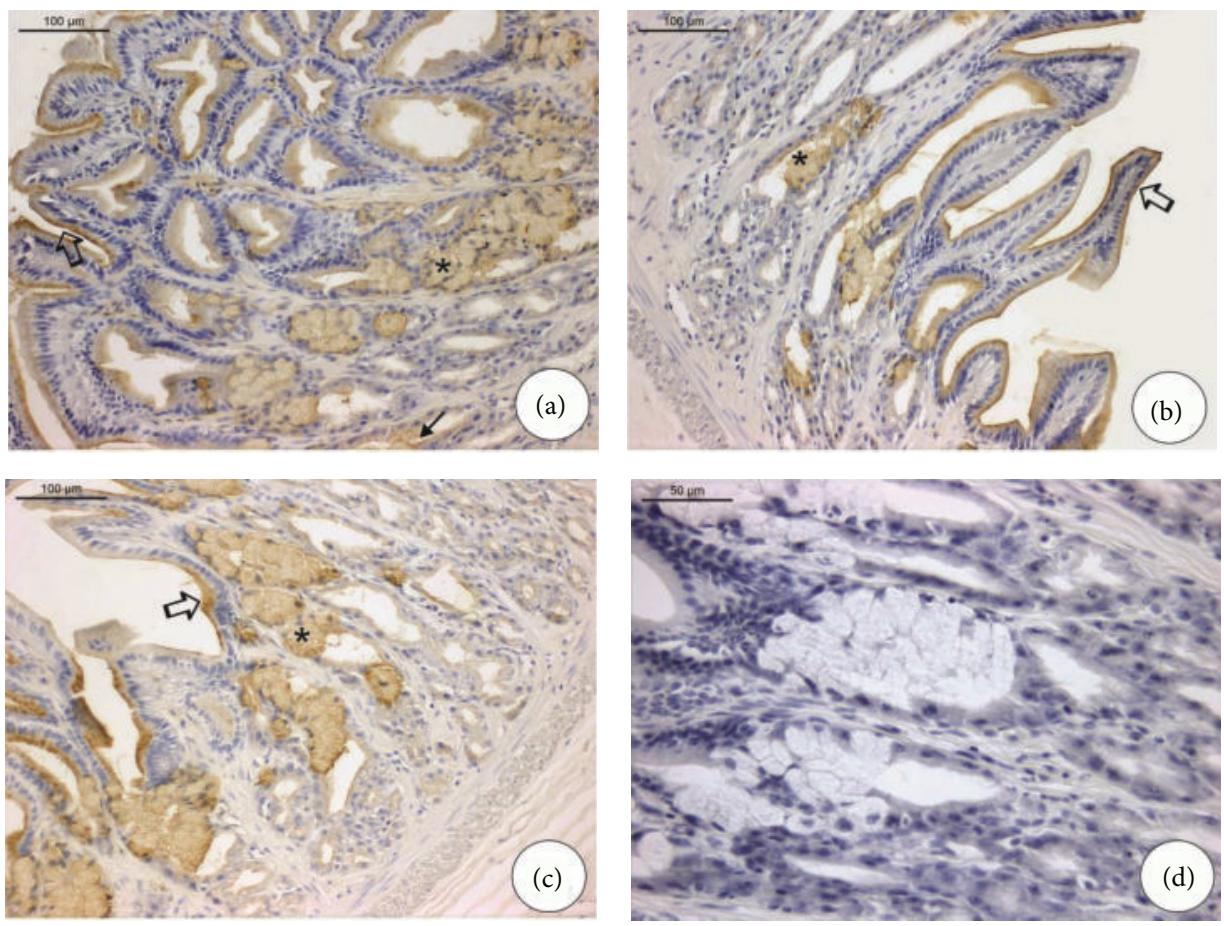

FIGURE 8: Lectin histochemistry. (a) Fundic region: the oxynticopeptic cells displayed a very weak positive reaction for GSL ( $\rightarrow$ ), in contrast to the epithelial cells $(\Rightarrow)$ and mucous neck cells $(\star)$. (b) Pyloric region: note the moderate reaction in epithelial cells $(\Rightarrow)$ and mucous neck cells $(\star)$ after PNA staining. (c) Pyloric region. Note the strong reaction at the apical domain of epithelial cells of the gastric pits as well as at mucous neck cells. (d) Negative control.

in nature of the oligosaccharide chains may occur between species of vertebrates.

In this study, oxynticopeptic cells revealed cytoplasmic acidophilic granules after staining with Gomori's trichrome. Norris [38] noticed that in $R$. pipiens the secretory granules of the oxynticopeptic cell are smaller and less numerous when compared to the pepsinogen granules of the frog esophageal glands.

Mannose-positive cells were also observed scattered throughout connective tissue of the mucosa and submucosal layers of the stomach of $R$. icterica, corresponding probably to mast cells, since they also exhibited alcianophilic reaction. Mast cells of lymph nodes as well as macrophage-like cells in the lung and in the liver exhibited mannose-specific binding sites [50].

Considering the gastrointestinal hormones, 5-HT, G, STT, glucagon, and CCK are the main hormones in mammals. 5-HT is an important neurotransmitter, able to stimulate contraction and vasodilatation of smooth muscle cells, displaying a strong regulatory role in digestive function [51]. These findings have established for the EC cells a promising research focus since EC cells are very sensitive to intestinal glucose, causing the 5-HT liberation. On the other hand, 5-HT activates neuronal receptors that stimulate gastric motility, inducing stomach emptying [52].

In anuran, different EC cell types were described in the stomach of larval phases, late metamorphosis, and adults. In tadpolesof Rana temporaria, EC cells were mainly located at the lining epithelium and occasionally found in glands $[5,53]$. Villaro and coworkers [53] related the fact that in
Rana temporaria 5-HT and STT secreting cells are the most frequent endocrine cell types, occurring along the entire stomach, as it was observed for R. icterica. In addition, STT secreting cells were not detected. Previous report indicated that 5-HT secreting cells occurred in later phases of development (metamorphosis) of the stomach of Alytes obstetricans [54]. Although studies on bufonids are scarce, El-Salhy and coworkers [8] identified 5-HT secreting cells (5-HT cells), STT-secreting cells (D cells), G-secreting cells (G cells), glucagon secreting cells (A cells), and bombesin secreting cells ( $\mathrm{P}$ cells) among the lining epithelium in gastric glands in $B$. regularis.

In $R$. icterica, the muscular layer showed similar pattern related to other amphibians as $R$. catesbeiana and X. laevis [51]. However, Norris [38] noticed that in $R$. pipiens the circular layer of muscularis is absent in lower portion of both fundic and pyloric regions.

This work showed that the stomach of $R$. icterica was similar to other anurans; moreover, 5-HT-IR cells occur among the lining epithelium and the mucous cells, occurring preferentially at the upper portion of the fundic glands. Considering glycoconjugates that contained $\alpha-, \beta$-Gal, and $\alpha$ GalNAc residues, they were also detected in the oxynticopeptic cells, what seems to be peculiar to this species.

\section{Conflict of Interests}

The authors declare that there is no conflict of interests regarding the publication of this paper. 


\section{Acknowledgments}

The authors acknowledge the financial support provided by FAPERJ-Fundação Carlos Chagas Filho de Amparo a Pesquisa do Estado do Rio de Janeiro; they also thank Professor Armando Sales for providing some antibodies aliquot for immunohistochemistry test.

\section{References}

[1] A. M. Anderson, D. A. Haukos, and J. T. Anderson, "Diet composition of three anurans from the playa wetlands of Northwest Texas," Copeia, no. 2, pp. 515-520, 1999.

[2] G. Menghi, L. Marchetti, M. G. Sabbieti, M. Menghi, and S. Materazzi, "In situ visualization of o-phthalate esters in gastrointestinal tract of the frog Rana esculenta," Histology and Histopathology, vol. 18, no. 2, pp. 371-377, 2003.

[3] S. K. Loo and W. C. Wong, "Histochemical observations on the mucins of the gastrointestinal tract in the toad (Bufo melanostictus)," Acta Anatomica, vol. 91, no. 1, pp. 97-103, 1975.

[4] G. Bani, L. Formigli, and R. Cecchi, "Morphological observations on the glands of the oesophagus and stomach of adult Rana esculenta and Bombina variegata," Italian Journal of Anatomy and Embryology, vol. 97, no. 2, pp. 75-87, 1992.

[5] J. Rovira, A. C. Villaro, M. E. Bodegas, E. Valverde, and P. Sesma, "Structural study of the frog Rana temporaria larval stomach," Tissue and Cell, vol. 25, no. 5, pp. 695-707, 1993.

[6] T. Ogata and Y. Yamasaki, "Ultra-high-resolution scanning electron microscopy of the continuity of cytoplasmic and luminal membranes in frog oxyntic cells," The Anatomical Record, vol. 245, no. 3, pp. 559-567, 1996.

[7] A. A. Pelli-Martins, C. Machado-Santos, A. Sales, and L. de Brito-Gitirana, "Histochemical, immunohistochemical, and ultrastructural observations of the esophagus morphology of Rinella icterica (Anuran, Bufonidae)," Acta Zoologica, vol. 93, no. 4, pp. 373-380, 2012.

[8] M. El-Salhy, L. Grimelius, E. Wilander, G. Abu-Sinna, and G. Lundqvist, "Histological and immunohistochemical studies of the endocrine cells of the gastrointestinal mucosa of the toad (Bufo regularis)," Histochemistry, vol. 71, no. 1, pp. 53-65, 1981.

[9] A. L. Kierszenbaum and L. L. Tres, Histology and Cell Biology: An Introduction to Pathology, Elsevier Saunders, Philadelphia, $\mathrm{Pa}$, USA, 2012.

[10] D. Ferri, G. E. Liquori, and G. Scillitani, "Morphological and histochemical variations of mucous and oxynticopeptic cells in the stomach of the seps, Chalcides chalcides," Journal of Anatomy, vol. 194, no. 1, pp. 71-77, 1999.

[11] D. G. Sheahan and H. R. Jervis, "Comparative histochemistry of gastrointestinal mucosubstances," The American Journal of Anatomy, vol. 146, no. 2, pp. 103-131, 1976.

[12] T. Suganuma, T. Katsuyama, M. Tsukahara, M. Tatematsu, Y. Sakakura, and F. Murata, "Comparative histochemical study of alimentary tracts with special reference to the mucous neck cells of the stomach," American Journal of Anatomy, vol. 161, no. 2, pp. 219-238, 1981.

[13] D. Ferri, G. E. Liquori, L. Natale, G. Santarelli, and G. Scillitani, "Mucin histochemistry of the digestive tract of the red-legged frog Rana aurora aurora," Acta Histochemica, vol. 103, no. 2, pp. 225-237, 2001.

[14] G. E. Liquori, G. Scillitani, M. Mastrodonato, and D. Ferri, "Histochemical investigations on the secretory cells in the oesophagogastric tract of the Eurasian green toad, Bufo viridis," The Histochemical Journal, vol. 34, no. 10, pp. 517-524, 2002.

[15] J. Gallego-Huidobro and L. M. Pastor, "Histology of the mucosa of the oesophagogastric junction and the stomach in adult Rana perezi," Journal of Anatomy, vol. 188, no. 2, pp. 439-444, 1996.

[16] M.-C. Ruiz, A. Acosta, M. J. Abad, and F. Michelangeli, "Nonparallel secretion of pepsinogen and acid by gastric oxyntopeptic cells of the toad (Bufo marinus)," The American Journal of Physiology-Gastrointestinal and Liver Physiology, vol. 265, no. 5, pp. G934-G941, 1993.

[17] D. Ferri and G. E. Liquori, "Characterization of secretory cell glycoconjugates in the alimentary tract of the ruin lizard (Podarcis sicula campestris) by means of lectin histochemistry," Acta Histochemica, vol. 93, no. 1, pp. 341-349, 1992.

[18] D. Ferri and G. E. Liquori, "Immunohistochemical investigations on the pyloric glands of the ruin lizard (Podarcis sicula campestris de Betta)," Acta Histochemica, vol. 96, no. 1, pp. 96103, 1994.

[19] M. Mastrodonato, G. Calamita, R. Rossi, G. Scillitani, G. E. Liquori, and D. Ferri, "Expression of $\mathrm{H}^{+}, \mathrm{K}^{+}$-ATPase and glycopattern analysis in the gastric glands of Rana esculenta," Journal of Histochemistry \& Cytochemistry, vol. 57, no. 3, pp. 215225, 2009.

[20] T. Shirakawa and B. I. Hirschowitz, "Interaction between stimuli and their antagonists on frog esophageal peptic glands," The American Journal of Physiology-Gastrointestinal and Liver Physiology, vol. 249, no. 6, pp. G668-G673, 1985.

[21] M. C. Ruiz, M. J. Abad, B. González, A. Acosta, and F. Michelangeli, "Comparison of acid and pepsinogen secretion control by oxyntopeptic cell of amphibians," Acta Cientifica Venezolana, vol. 44, no. 2, pp. 89-94, 1993.

[22] G. E. Liquori, S. Zizza, M. Mastrodonato, G. Scillitani, G. Calamita, and D. Ferri, "Pepsinogen and H,K-ATPase mediate acid secretion in gastric glands of Triturus carnifex (Amphibia, Caudata)," Acta Histochemica, vol. 107, no. 2, pp. 133-141, 2005.

[23] M. A. Tzaneva, "Ultrastructural immunohistochemical localization of gastrin, somatostatin and serotonin in endocrine cells of human antral gastric mucosa," Acta Histochemica, vol. 105, no. 2, pp. 191-201, 2003.

[24] S. K. Ku, H. S. Lee, and J. H. Lee, "An immunohistochemical study of the gastrointestinal endocrine cells in the C57BL/6 mice," Anatomia Histologia Embryologia, vol. 32, no. 1, pp. 2128, 2003.

[25] C. Fink, M. Tatar, K. Tatar, R. Hospes, M. Kressin, and K. Klisch, "Serotonin-containing cells in the gastrointestinal tract of newborn foals and adult horses," Journal of Veterinary Medicine Series C: Anatomia Histologia Embryologia, vol. 35, no. 1, pp. 23-27, 2006.

[26] C. M. Santos, A. A. Nascimento, A. L. Peracchi, D. Dias, T. P. Ribeiro, and A. Sales, "A comparative immunohistochemical study of endocrine cells in the digestive tract of two frugivorous bats: Artibeus cinerius and Sturnira lilium," Acta Histochemica, vol. 110, no. 2, pp. 134-142, 2008.

[27] K. Sugimoto, Y. Ichikawa, and I. Nakamura, "Peroxidase activity in the epithelium of the digestive tract of the bullfrog, Rana catesbeiana," The Journal of Experimental Zoology, vol. 233, no. 2, pp. 209-219, 1985.

[28] O. D. De Rada, P. Sesma, and J. J. Vazquez, "Endocrine cells of the gastric mucosa of Rana temporia L," Histology and Histopathology, vol. 2, no. 2, pp. 119-128, 1987.

[29] G. Wang, Y. Wang, D. Ma et al., "Five novel antimicrobial peptides from the Kuhl's wart frog skin secretions, Limnonectes 
kuhlii," Molecular Biology Reports, vol. 40, no. 2, pp. 1097-1102, 2013.

[30] J. M. Conlon and A. Sonnevend, "Antimicrobial peptides in frog skin secretions," Methods in Molecular Biology, vol. 618, pp. 3-14, 2010.

[31] H. S. Kim, H. Yoon, I. Minn et al., "Pepsin-mediated processing of the cytoplasmic histone $\mathrm{H} 2 \mathrm{~A}$ to strong antimicrobial peptide buforin I," The Journal of Immunology, vol. 165, no. 6, pp. 32683274, 2000.

[32] I. Minn, H. S. Kim, and S. C. Kim, "Antimicrobial peptides derived from pepsinogens in the stomach of the bullfrog, Rana catesbeiana," Biochimica et Biophysica Acta-Molecular Basis of Disease, vol. 1407, no. 1, pp. 31-39, 1998.

[33] J. H. Cho, B. H. Sung, and S. C. Kim, "Buforins: histone H2Aderived antimicrobial peptides from toad stomach," Biochimica et Biophysica Acta-Biomembranes, vol. 1788, no. 8, pp. 15641569, 2009.

[34] R. D. Lillie and H. M. Fullmer, Histopathologic Technique and Practical Histochemistry, MacGraw-Hill, New York, NY, USA, 4th edition, 1976.

[35] J. A. Kiernan, Histological \& Histochemical Methods-Theory and Practice, Pergamon Press, Frankfurt, Germany, 2nd edition, 1990.

[36] D. I. Patt and G. R. Patt, Comparative Vertebrate Histology, Harper \& Row, New York, NY, USA, 1969.

[37] R. Paniagua and M. Nista, Introducción a la Histologia Animal Comparada, Labor, Barcelona, Spain, 1983.

[38] J. L. Norris, “The normal histology of the esophageal and gastric mucosae of the frog, Rana pipiens," The Journal of Experimental Zoology, vol. 141, no. 1, pp. 155-173, 1959.

[39] D. M. Smith, R. C. Grasty, N. A. Theodosiou, C. J. Tabin, and N. M. Nascone-Yoder, "Evolutionary relationships between the amphibian, avian, and mammalian stomachs," Evolution and Development, vol. 2, no. 6, pp. 348-359, 2000.

[40] M. Derrien, M. van Passel, J. van de Bovenkamp, R. Schipper, W. M. de Vos, and J. Dekker, "Mucin-bacterial interactions in the human oral cavity and digestive tract," Gut Microbes, vol. 1, no. 4, pp. 254-268, 2010.

[41] W. D. Kuhlmann, P. Peschke, and K. Wurster, "Lectinperoxidase conjugates in histopathology of gastrointestinal mucosa," Virchows Archiv A Pathological Anatomy and Histology, vol. 398, no. 3, pp. 319-328, 1983.

[42] C. M. Santos, S. Duarte, T. G. Sousa, T. P. Ribeiro, A. Sales, and F. G. Araújo, "Histologia e caracterização histoquímica do tubo gastrintestinal de Pimelodus macu latus (Pimelodidae, Siluriformes) no reservatório de Funil, Rio de Janeiro, Brasil," Iheringia, vol. 97, pp. 78-82, 2007.

[43] G. E. Liquori, M. Mastrodonato, S. Zizza, and D. Ferri, "Glycoconjugate histochemistry of the digestive tract of Triturus carnifex (Amphibia, Caudata)," The Journal of Molecular Histology, vol. 38, no. 3, pp. 191-199, 2007.

[44] A. E. Fry and J. C. Kaltenbach, "Histology and lectin-binding patterns in the digestive tract of the carnivorous larvae of the anuran, Ceratophrys ornata," Journal of Morphology, vol. 241, pp. 19-32, 1999.

[45] G. Scillitani, D. Mentino, G. E. Liquori, and D. Ferri, "Histochemical characterization of the mucins of the alimentary tract of the grass snake, Natrix natrix (Colubridae)," Tissue and Cell, vol. 44, no. 5, pp. 288-295, 2012.

[46] P. Peschke, W. D. Kuhlmann, and K. Wurster, "Histological detection of lectin binding sites in human gastrointestinal mucosa," Experientia, vol. 39, no. 3, pp. 286-287, 1983.
[47] M. Ito, K. Takata, S. Saito, T. Aoyagi, and H. Hirano, "Lectinbinding pattern in normal human gastric mucosa-a light and electron microscopic study," Histochemistry, vol. 83, no. 4, pp. 189-193, 1985.

[48] N. Kessimian, B. J. Langner, P. N. McMillan, and H. O. Jauregui, "Lectin binding to parietal cells of human gastric mucosa," Journal of Histochemistry and Cytochemistry, vol. 34, no. 2, pp. 237-243, 1986.

[49] G. E. Liquori, D. Ferri, and G. Scillitani, "Fine structure of the oxynticopeptic cells in the gastric glands of the ruin lizard, Podarcis sicula campestris (De Betta , 1857)," The Histochemical Journal, vol. 243, no. 2, pp. 167-171, 2000.

[50] W. Straus, "Mannose-specific binding sites for horseradish peroxidase in various cells of the rat," Journal of Histochemistry and Cytochemistry, vol. 31, no. 1, pp. 78-84, 1983.

[51] M. Yoshida, "A light microscope study of the distribution of muscle in the frog esophagus and stomach," Journal of Smooth Muscle Research, vol. 37, no. 3-4, pp. 95-104, 2001.

[52] H. E. Raybould, J. Glatzle, C. Robin et al., "Expression of 5HT3 receptors by extrinsic duodenal afferents contribute to intestinal inhibition of gastric emptying," The American Journal of Physiology-Gastrointestinal and Liver Physiology, vol. 284, no. 3, pp. G367-G372, 2003.

[53] A. C. Villaro, J. Rovira, M. E. Bodegas, M. A. Burrell, D. GarcíaRos, and P. Sesma, "Immunocytochemical and ultrastructural characterization of endocrine cells in the larval stomach of the frog Rana temporaria tadpoles: a comparison with adult specimens," Tissue and Cell, vol. 33, no. 5, pp. 462-477, 2001.

[54] A. L'Hermite, J. Hourdry, and R. Ferrand, "Investigations of endocrine cells in the gastrointestinal tract and pancreas during the metamorphosis of an anuran (Alytes obstetricans L.): histochemical detection of APUD cells," General and Comparative Endocrinology, vol. 69, no. 3, pp. 381-390, 1988. 

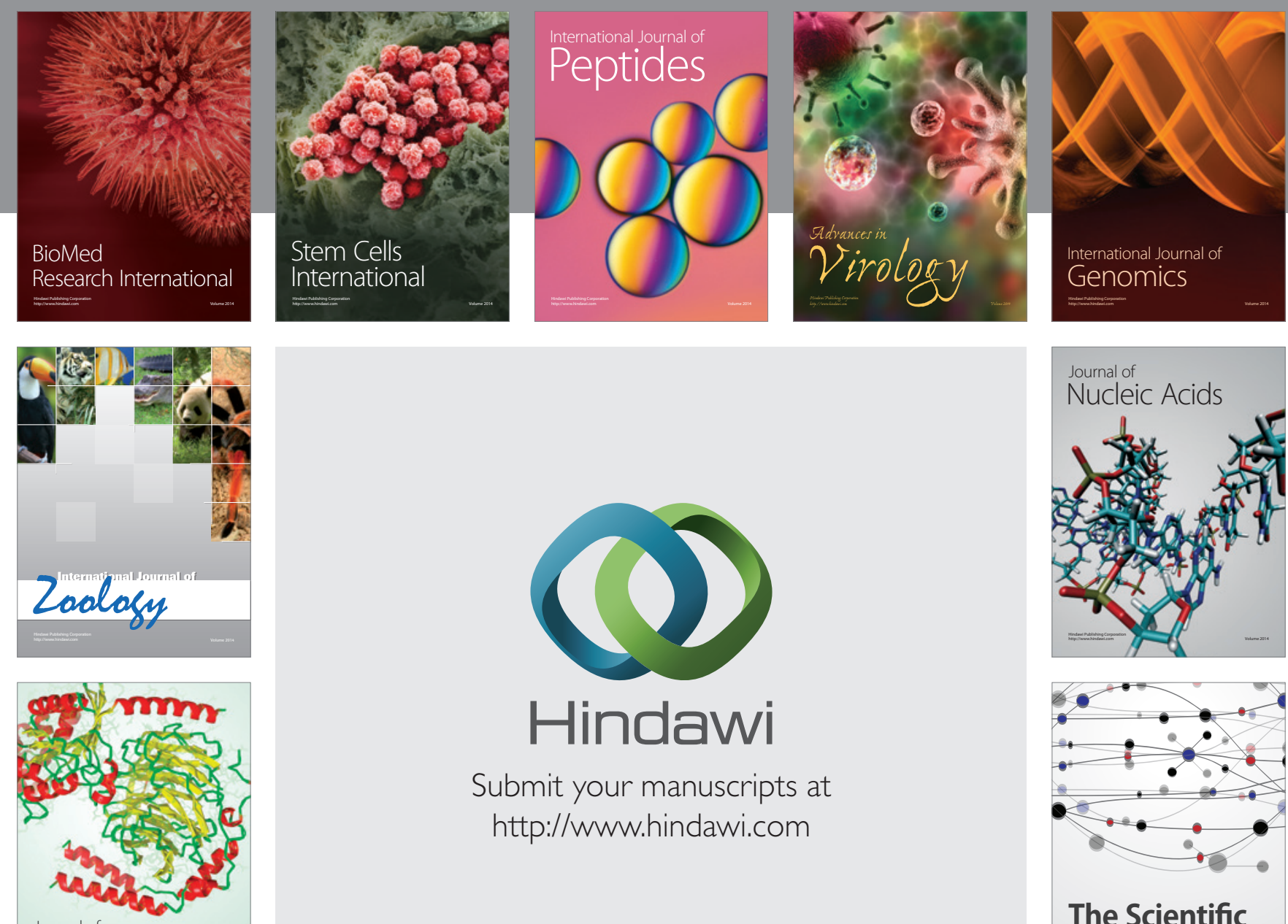

Submit your manuscripts at

http://www.hindawi.com

Journal of
Signal Transduction
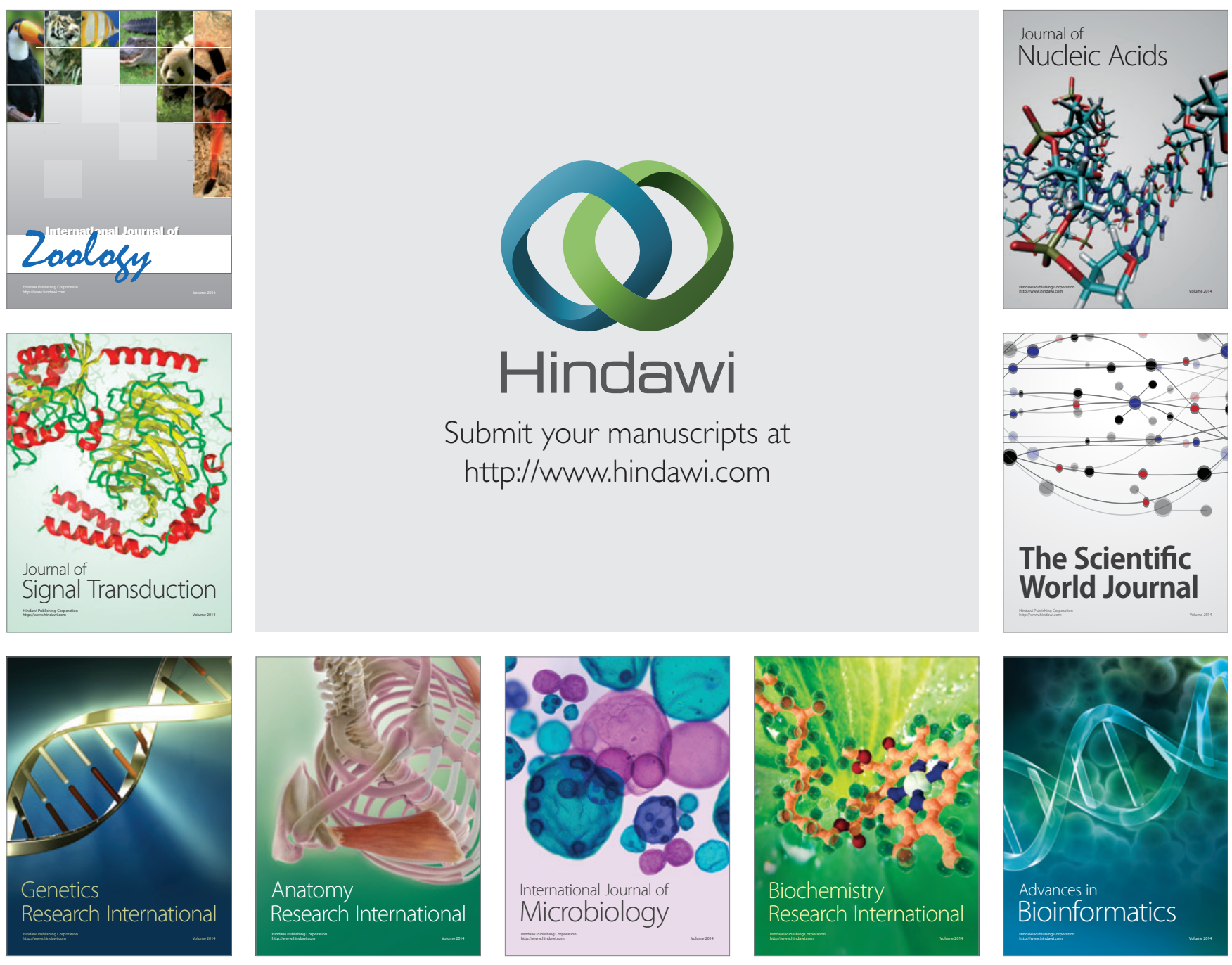

The Scientific World Journal
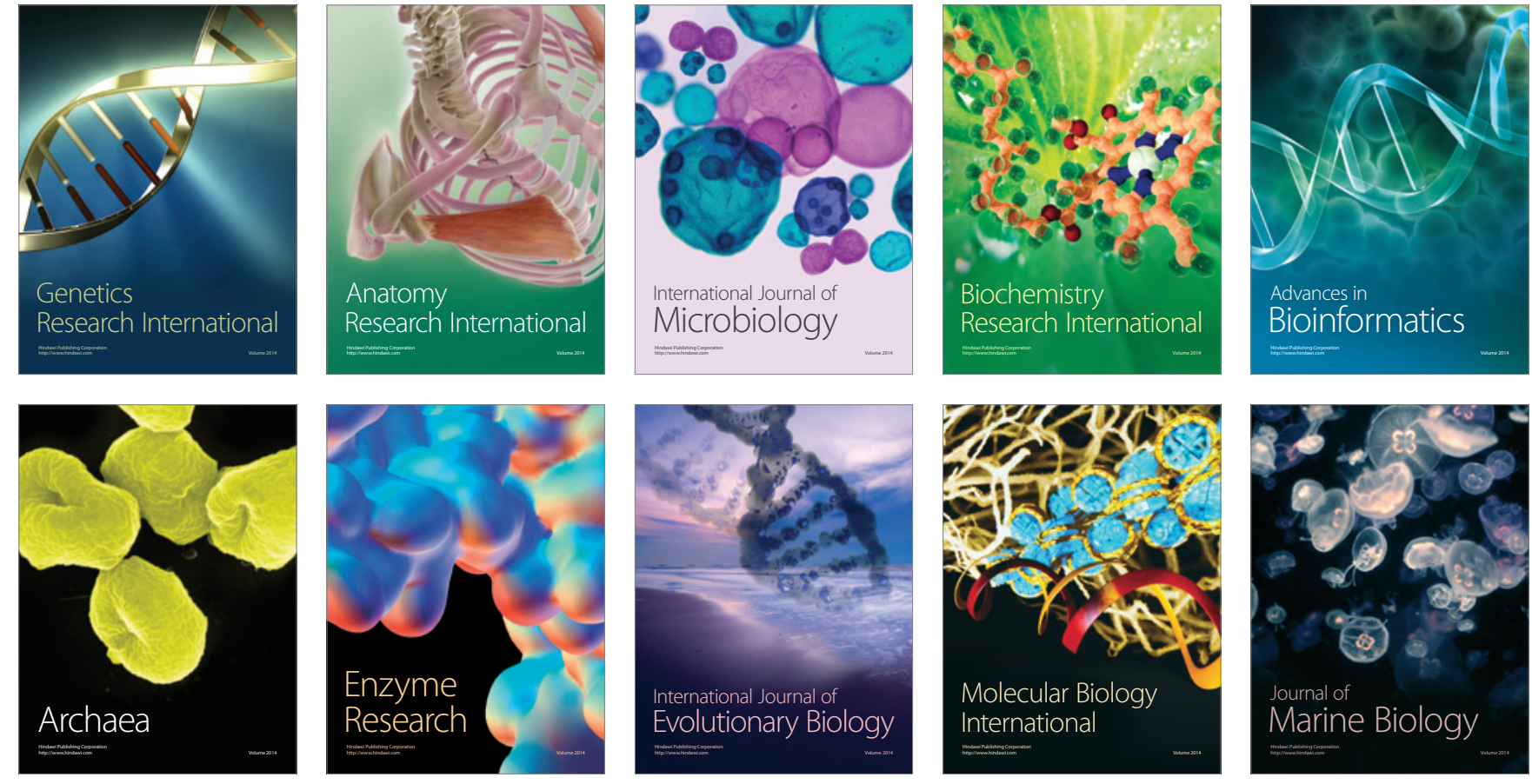